\title{
PELATIHAN PENYUSUNAN RENCANA ANGGARAN BIAYA INFRASTRUKTUR DESA BAGI PERANGKAT DESA DI DESA KARANGBENDO KECAMATAN ROGOJAMPI
}

\author{
Yuni Ulfiyati\#1, M. Shofiul Amin*2, Mirza Ghulam R\#3, Sari Wiji Utami*4 \\ \#1,23,4Program Studi Teknik Sipil, Politeknik Negeri Banyuwangi \\ Jl. Raya Jember Km. 13, Labanasem, Kabat, Banyuwangi \\ 1yuniulfi67@gmail.com \\ 2ofy.civil@gmail.com \\ 3mirza@poliwangi.ac.id \\ 4sariwijiutami@gmail.com
}

\begin{abstract}
ABSTRAK
Upaya peningkatan infrastruktur untuk pelayanan masyarakat semakin banyak dilakukan di setiap daerah. Seiring dengan upaya tersebut, perangkat desa yang diharapkan bisa menjadi perantara berjalannya program peningkatan infrastruktur dituntut untuk mempunyai kemampuan dalam menjalankan kegiatan teknis pelaksanaan pembangunan dilapangan. Dalam kegiatan pembangunan infrastruktur desa, penyusunan rencana anggaran biaya adalah hal yang sangat penting dan harus dikuasai agar kegiatan dapat berjalan sesuai rencana dengan target biaya, mutu dan waktu yang efektif dan efisien. Mitra yang bekerjasama dalam kegiatan ini akan di bimbing dan menerima penyuluhan tentang penyusunan rencana anggaran biaya. Pelaksanaan kegiatan ini meliputi kegiatan sosialisasi/pengenalan tentang rencana anggaran biaya dan komponen penyusunnya, pembahasan analisa harga satuan pekerjaan, penjelasan tentang cara perhitungan volume pekerjaan dan pelatihan penyusunan rencana anggaran biaya sampai tersusun sebuah dokumen rencana anggaran biaya untuk infrastruktur desa. Luaran yang didapatkan adalah tersusunnya modul anggaran biaya yang dapat digunakan oleh perangkat desa dalam rangka kegiatan perencanaan pembangunan di desanya. Selain itu dengan kegiatan pengabdian ini diharapkan para perangkat desa memiliki tambahan pengetahuan dan keterampilan dalam penyusunan anggaran biaya infrastruktur desa.
\end{abstract}

Keywords- Pelatihan, RAB, Infrastruktur

\section{PENDAHULUAN}

Rencana Anggaran Biaya (RAB) merupakan perencanaan detail dari sebuah kegiatan dalam sebuah proyek, baik itu proyek non konstruksi maupun proyek konstruksi. Dalam pembangunan infrastruktur desa RAB memberikan gambaran dan panduan mengenai perkiraan biaya yang dibutuhkan dalam penyelesaian sebuah proyek pembangunan infrastruktur desa. Pembuatan RAB minimal harus dibuat oleh dua pihak, yaitu pihak yang akan memberikan pekerjaan (owner) dan pihak yang akan melaksanakan pekerjaan. Apabila kedua pihak tersebut menguasai dan memahami tentang penyusunan dan standar dalam perencanaan anggaran biaya, maka akan didapatkan persepsi dan pemahaman yang sama mengenai rencana anggaran biaya yang ditetapkan sebagai acuan dalam pelaksanaan pekerjaan.

Seiring dengan upaya pemerintah untuk peningkatan pelayanan masyarakat, perangkat desa yang diharapkan bisa menjadi perantara berjalannya program pada sebuah desa dituntut untuk mempunyai kemampuan dalam perencanaan anggaran biaya. Pentingnya perencanaan anggaran biaya sehingga membutuhkan perangkat-perangkat 
desa yang mengerti bagaimana penyusunan RAB yang benar. Agar perangkat desa bisa memenuhi fungsi perencana tersebut, maka perlu dilakukan pelatihan penyusunan rencana anggaran biaya agar dana yang ada bisa dikelola secara bijak dan bermanfaat.

Desa Karangbendo adalah salah satu instansi yang memiliki wewenang untuk memanfaatkan dana pembangunan infrastruktur desa. Dalam kegiatan perencanaan anggaran, perangkat desa harus mampu menyusun rencana anggaran biaya dengan benar. Kondisi yang ada saat ini, belum sepenuhnya perangkat desa menguasai cara penyusunan RAB sesuai aturan yang berlaku. Pengetahuan akan pembuatan dan penyusunan RAB hanya dimiliki oleh beberapa perangkat desa. Hal ini menyebabkan sering terjadinya perbedaan persepsi karena perangkat desa tidak mempunyai pengetahuan yang memadai tentang perencanaan anggaran biaya. Berdasarkan kondisi ini maka perangkat desa Desa Karangbendo sebagai mitra dalam kegiatan Ipteks bagi masyarakat perlu untuk menerima pelatihan mengenai penyusunan rencana anggaran biaya untuk pembangunan infrastruktur desa. Peserta pelatihan adalah dari perangkat desa pada Desa Karangbendo sebanyak 20 orang. Diharapkan dari kegiatan ini perangkat desa mampu menyusun rencana anggaran biaya infrastruktur desa agar bisa digunakan untuk pengelolaan dana pembangunan desa secara efektif.

Permasalahan pada mitra yaitu minimnya pengetahuan rata-rata perangkat desa tentang penyusunan rencana anggaran biaya serta analisa harga yang diperoleh untuk bisa merencanakan anggaran yang efektif. Pengetahuan yang dimiliki perangkat desa masih sangat timpang. Ada perangkat desa yang benar-benar paham mengenai $R A B$, tetapi masih banyak juga yang tidak paham sama sekali tentang RAB dan cara penyusunannya sesuai standar yang berlaku saat ini. Karena kondisi ini sering terjadi perbedaan persepsi dalam penghitungan volume pekerjaan yang menghasilkan besaran biaya yang berbeda. Untuk itu perlu dilakukan pelatihan penyusunan rencana anggaran biaya yang benar sesuai dengan standard dan aturan yang berlaku agar kegiatan perencanaan anggaran biaya dan kegiatan bisa berjalan dengan baik dan bisa dipertanggung jawabkan.

\section{TARGET DAN LUARAN}

Target dari kegiatan ini adalah agar perangkat desa di Desa Karangbendo bisa melakukan penyusunan rencana anggaran biaya untuk kegiatan pembangunan infrastruktur desa dengan baik dan benar. Dalam kegiatan ini target peserta yang hadir sebanyak dua puluh orang perangkat desa. Target ini akan diupayakan tercapai dengan dilakukan serangkaian kegiatan pelatihan pembuatan dan penyusunan rencana anggaran biaya secara langsung, sehingga setelah pelatihan para perangkat desa bisa menyusun rencana anggaran biaya sendiri.

Luaran dari kegiatan ini adalah perangkat desa mampu memahami tentang rencana anggaran biaya, menghitung volume pekerjaan, menerapkan analisa harga satuan dan mampu menyusun rencana anggaran biaya yang bisa dijadikan pedoman ketika ada kegiatan pembangunan infrastruktur desa. Luaran lain yang dihasilkan adalah artikel ilmiah yang akan dipublikasikan pada jurnal pengabdian masyarakat dan modul penyusunan rencana anggaran biaya yang diharapkan bisa menjadi panduan dalam penyusunan $\mathrm{RAB}$ untuk pembangunan infrastruktur desa.

\section{METODE PELAKSANAAN}

Kegiatan pengabdian ini akan dilakukan dalam beberapa tahapan meliputi:

A. Analisis kebutuhan dan Pendataan peserta

Kegiatan pengabdian ini diawali dengan melakukan kunjungan dan komunikasi dengan Kepala desa Karangbendo untuk mendapatkan informasi mengenai pelatihan yang diperlukan dan menentukan peserta yang akan melaksanakan pelatihan penyusunan 
rencana anggaran biaya untuk pembangunan infrastruktur desa. Berdasarkan hasil diskusi yang dilakukan dengan kepala desa, peserta pelatihan adalah perangkat desa yang terlibat secara langsung dalam kegiatan perencanaan dan pembangunan infrastruktur desa. Selain perangkat desa, kegiatan ini juga melibatkan mahasiswa untuk mendampingi peserta pelatihan ketika melakukan penyusunan rencana anggaran biaya.

B. Penyiapan lokasi dan sarana prasarana pelatihan

Untuk kelancaran kegiatan pelatihan, maka dilakukan penyiapan lokasi dan prasarana pelatihan. Dalam kegiatan pengabdian ini kepala desa dan perangkat desa berperan aktif dan sangat membantu kelancaran kegiatan. Sarana dan prasarana kegiatan pelatihan meliputi ruangan dan komputer disediakan oleh perangkat Desa Karangbendo. Tim pelaksana kegiatan mempersiapkan materi, modul penyusunan rencana anggaran biaya, analisa harga satuan pekerjaan dan daftar harga upah bahan sesuai standar pemeritah daerah Kabupaten Banyuwangi tahun 2017.

\section{Pelaksanaan Kegiatan}

1. Sosialisasi Kegiatan Pelatihan

Pelaksanaan kegiatan sosialisasi di desa Karangbendo dilakukan pada hari jum `at tanggal 6 Oktober 2017. Kegiatan sosialisasi dilakukan di pendopo Desa Karangbendo yang diikuti oleh para perangkat desa dan juga dihadiri oleh kepala Desa Karangbendo. Dalam kegiatan sosialisasi tersebut, ketua tim kegiatan pengabdian menjelaskan tujuan kegiatan pengabdian masyarakat. Para perangkat Desa Karangbendo sangat antusias dan berperan aktif dalam diskusi dan Tanya jawab dengan para narasumber mengenai permasalahan penyusunan rencana anggaran biaya yang selama ini terjadi pada daerah mereka. Dokumentasi kegiatan sosialisasi disajikan pada Gambar 1

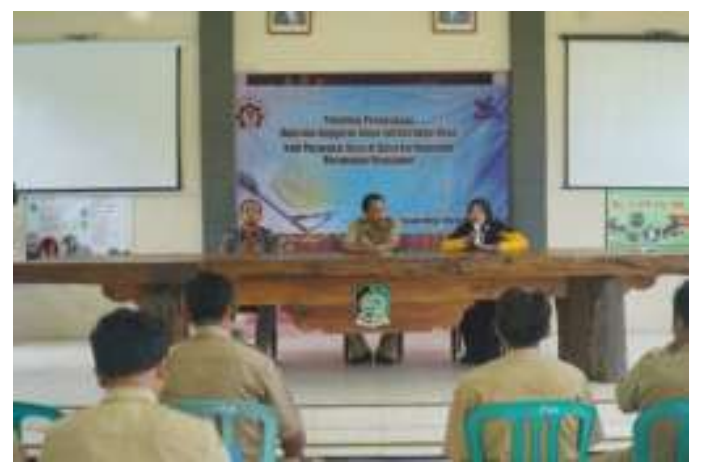

Gambar 1 Sosialisasi Kegiatan Pengabdian Masyarakat

2. Pelatihan Penyusunan RAB

Kegiatan Pelatihan penyusunan rencana anggaran biaya di desa Karangbendo dilakukan pada hari senin tanggal 16 Oktober 2017, tanggal 28 Oktober dan kegiatan tanggal 2 November 2017. Kegiatan pelatihan ini dilakukan di ruang pelayanan Desa Karangbendo yang diikuti oleh para perangkat Desa Karangbendo. Dalam kegiatan pelatihan ini para perangkat desa diberikan materi mengenai cara menghitung volume pekerjaan, Analisa Harga Satuan Pekerjaan dan pelatihan untuk menghitung secara langsung rencana anggaran biaya untuk bangunan gedung, infrastruktur jalan dan pekerjaan saluran. Dalam pelaksanaan kegiatan pelatihan, peserta menghitung volume pekerjaan dan kemudian menghitung anggaran biaya setelah dikalikan dengan analisa harga satuan standar yang berlaku di wilayah Banyuwangi tahun 2017. Dalam pelaksanaan pelatihan di lapangan proses perhitungan menggunakan Microsoft excel untuk mempercepat perhitungan. Pelaksanaan kegiatan pengabdian ini juga melibatkan mahasiswa untuk mendampingi para peserta pelatihan.

Dalam pelaksanaan kegiatan, ada kendala mengenai penjadwalan waktu pelaksanaan pelatihan, karena para 
perangkat desa juga harus bekerja untuk melakukan kegiatan pelayana di desa. Kendala tersebut menyebabkan kegiatan tidak bisa dilakukan kontinu, sehingga pelatihan dilaksanakan menyesuaikan jadwal perangkat desa karangbendo. Pada diakhir kegiatan dibagikan sertifikat kepada seluruh peserta kegiatan dan panitia. Dokumentasi kegiatan pelatihan penyusunan rencana anggaran biaya ditampilkan pada Gambar 2

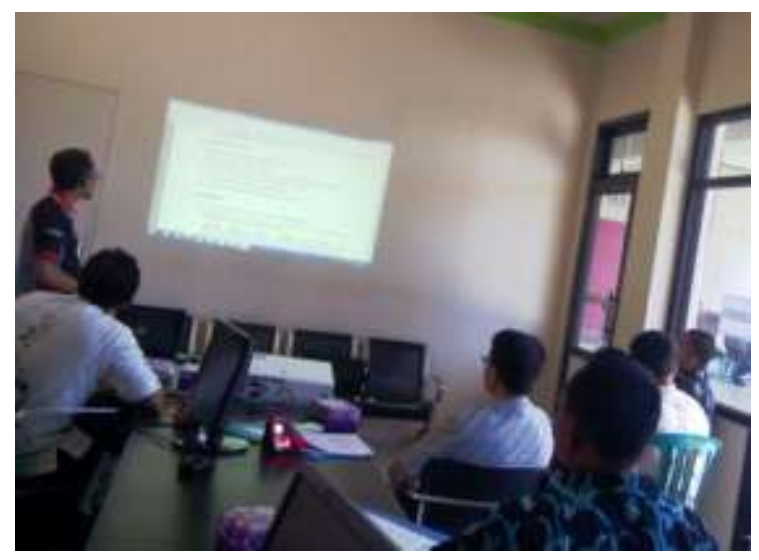

Gambar 2. Kegiatan Pelatihan Penyusunan RAB

\section{Hasil dan Luaran}

Kegiatan Pelatihan penyusunan rencana anggaran biaya di desa Karangbendo memperoleh hasil dan luaran sebagai berikut:
a. Modul pelatihan dan Sertifikat
b. Publikasi pada media cetak
c. Publikasi pada Jurnal pengabdian masyarakat

\section{KELAYAKAN PERGURUAN TINGGI}

Dalam kurun lima tahun terakhir, Pusat Pengabdian Masyarakat (PPPM) Politeknik Negeri Banyuwangi memiliki kinerja yang baik berkaitan dengan penelitian dan pengabdian kepada masyarakat. PPPM Politeknik Negeri Banyuwangi telah bekerjasama dengan pemerintah daerah Banyuwangi dan mendapat dukungan pendanaan untuk kegiatan penelitian dan pengabdian masyarakat. Selain bekerjasama dengan pemerintah daerah, telah banyak dilakukan kegiatan pengabdian masyarakat dengan dana hibah dari pemerintah pusat.

Tim pelaksana dalam kegiatan pengabdian ini terdiri dari 4 orang dosen dengan bidang kepakaran sesuai kebutuhan untuk kegiatan pelatihan penyusunan rencana anggaran biaya infrastruktur desa. Dalam pelatihan ini diperlukan bidang kepakaran manajemen konstruksi, manajemen infrastuktur dan ahli perencanaan struktur gedung,a jalan dan saluran. Selain tim pelaksana dari dosen, juga dilibatkan mahasiswa sebagai pendukung ketika mendampingi peserta dalam melakukan perhitungan dan penyusunan rencana anggaran biaya. Kegiatan pengabdian ini melibatkan dosen dan mahasiswa dengan harapan peran keberadaan perguruan tinggi lebih terasa manfaatnya untuk peningkatan pengetahuan dan kemampuan masyarakat sekitar Politeknik Negeri Banyuwangi.

\section{HASIL DAN LUARAN YANG DICAPAI}

Kegiatan pengabdian pada masyarakat di Desa Karangbendo ini dilaksanakan berdasarkan hasil komunikasi dan diskusi dengan kepala desa dan perangkat desa karangbendo. Kegiatan pelatihan penyusunan rencana anggaran biaya infrastruktur desa ini memberikan hasil sebagai berikut: (1) perangkat desa karangbendo dapat mengerti komponen-komponen penyusun rencana anggaran biaya;(2) perangkat desa karangbendo dapat memahami penggunaan analisa harga satuan pekerjaan;(3) perangkat desa karangbendo dapat memahami bagaimana melakukan perhitungan volume pekerjaan gedung, jalan dan pekerjaan saluran;(4) perangkat desa karangbendo dapat menyusun rencana anggaran biaya untuk pekerjaan gedung, jalan dan pekerjaan saluran.

Secara garis besar materi yang diberikan pada pelatihan tersebut adalah:

A. Pengenalan tentang RAB dan komponen penyusunnya

Pengenalan tentang RAB memberikan pengetahuan kepada perangkat desa tentang kegunaan RAB dan komponenkomponen penyusun $\mathrm{RAB}$ yang sudah 
ditetapkan analisanya dan juga harga upah serta bahan sesuai jenis pekerjaan dan kondisi masing masing lokasi. Dalam pengenalan RAB ini dijelaskan beberapa data yang diperlukan meliputi gambar kerja, spesifikasi pekerjaan, analisa harga satuan pekerjaan serta daftar harga upah dan bahan sesuai standard dan waktu pelaksanaan kegiatan pembangunan sebuah proyek dilakukan dilapangan.

B. Perhitungan Volume Pekerjaan

Pada tahap ini perangkat desa diberikan materi tentang bagaimana menghitung volume pekerjaan sesuai gambar kerja dan spesifikasi yang telah ditentukan. Masing-masing perangkat desa praktek secara langsung untuk menghitung volume sesuai gambar kerja yang sudah disediakan oleh tim pelaksana kegiatan. Volume pekerjaan yang dihitung oleh perangkat desa adalah volume pekerjaan gedung sederhana, volume pekerjaan jalan desa dan volume pekerjaan saluran. Tahapan dalam perhitungan volume pekerjaan memerlukan waktu yang cukup lama sehingga pelatihan ini dibagi dalam beberapa hari sesuai jenis pekerjaan yang sering dilakukan di desa. Pelatihan dilakukan selama tiga hari yaitu pada tanggal 16 Oktober 2017, 28 Oktober 2017 dan tanggal 2 November 2017.

Pada pertemuan pertama dilakukan pelatihan perhitungan volume pekerjaan gedung. Setelah itu perangkat desa menyusun rencana anggaran biaya pekerjaan gedung dengan mengalikan volume pekerjaan dengan analisa harga satuan pekerjaan sesuai HSPK Banyuwangi 2017. Pada pertemuan kedua dan ketiga dilakukan pelatihan perhitungan volume pekerjaan jalan dan saluran. Setelah itu perangkat desa menyusun rencana anggaran biaya pekerjaan jalan dan saluran.
C. Penyusunan RAB dan komponennya Setelah seluruh volume pekerjaan dihitung dan dikalikan dengan analisa harga satuan masing-masing sesuai jenis pekerjaan maka dilakukan rekapitulasi anggaran biaya. Sebagai lampiran disertakan gambar kerja, spesifikasi kegiatan, daftar harga upah dan bahan serta analisa harga satuan kegiatan daerah Banyuwangi tahun 2017. Setelah pelatihan selesai masing-masing perangkat desa memiliki dokumen rencana anggaran biaya untuk pekerjaan gedung, pekerjaan jalan dan pekerjaan saluran dari hasil perhitungan yang dilakukan masing-masing peserta. Setiap perangkat desa juga diberikan sertifikat dan modul penyusunan anggaran biaya beserta komponen-komponen penyusunnya yang diharapkan bisa menjadi panduan untuk menyusun rencana anggaran biaya sesuai standar.

\section{KESIMPULAN DAN SARAN}

\section{Kesimpulan}

Berdasarkan kegiatan pelatihan yang telah dilakukan, dapat disimpulkan bahwa pelatihan penyusunan rencana anggaran biaya infrastruktur desa ini dapat meningkatkan kemampuan para perangkat desa dalam melakukan perencanaan anggaran biaya untuk pembangunan infrastruktur desa. Melalui pelatihan ini perangkat desa memperoleh tambahan pengetahuan tentang bagaimana menyusun rencana anggaran biaya untuk pekerjaan gedung, jalan dan saluran sesuai standard yang berlaku di daerah Banyuwangi. Pelatihan penyusunan rencana anggaran biaya bagi para perangkat desa diperlukan agar para perangkat desa mempunyai kemampuan dan pemahaman yang sama dalam merencanaka anggaran biaya bagi pekerjaan infrastruktur desa.Setelah Pelatihan penyusunan rencana anggaran 
biaya ini dilaksanakan peserta pelatihan akan mendapatkan tambahan pengetahuan dan keterampilan serta sertifikat dan dokumen penyusunan rencana anggaran biaya yang bisa dijadikan pedoman dalam penyusunan rencana anggaran biaya untuk pembangunan infrastruktur desa.

\section{Saran}

Saran yang dapat diberikan yaitu perlu adanya keberlanjutan dari proses pelatihan yang sudah dilakukan dengan pengembangan metode penyusunan anggaran biaya yang lebih cepat menggunakan program. Proses pelatihan penyusunan rencana anggaran biaya sebaiknya melibatkan lebih banyak perangkat desa sampai ke pelaksana tingkat bawah agar dicapai pemahama yang sama mengenai perencanaan anggaran biaya dan penyusunannya sesuai standard.

\section{DAFTAR PUSTAKA}

Djojowirono, S., 2005. Manajemen konstruksi. Yogyakarta: Biro Penerbit Gramedia Pustaka Utama.

Ibrahim, B., 1993. Rencana dan Estimate Real of cost. Jakarta: Bumi Aksara.

Imam, S., 1998. Manajemen Proyek: Dari Konseptual Sampai Oprasional Jilid 2. Erlangga, Jakarta.

Tenriajeng, A.T., 2004. Administrasi Kontrak Dan Anggaran Borongan.

Kementrian Pekerjaan Umum. 2012, Pedoman Bahan Konstruksi Bangunan dan Rekayasa Sipil.

Keputusan Menteri Pemukiman dan Prasarana Wilayah Nomor 332/KPTS/M/2002. 2002. Pedoman Teknis Bangunan Gedung Negara, Jakarta. 